\title{
High Expression of Parathyroid Hormone-related Protein and Tumor Necrosis Factor- $\alpha$ in Cancer Cells as Risk Factors for Hypercalcemia in Bone Metastases Lytic Lesions
}

Made Wahyu Dharmapradita* ${ }^{1 *}$ I Ketut Suyasa ${ }^{2}$, Made Bramantya Karna ${ }^{2}$, I Wayan Juli Sumadi ${ }^{3}$, Kadek Gede Bakta Giri ${ }^{1}$, Cokorda Krishna Dalem Pemayun ${ }^{1}$, Claudia Santosa ${ }^{1}$

${ }^{1}$ Department of Orthopaedics and Traumatology, Resident of Orthopaedics and Traumatology, Faculty of Medicine, Udayana University, Sanglah General Hospital, Denpasar, Bali, Indonesia; ${ }^{2}$ Department of Orthopaedics and Traumatology, Faculty of Medicine, Udayana University, Sanglah General Hospital, Denpasar, Bali, Indonesia; ${ }^{3}$ Deparment of Anatomical Pathology, Faculty of Medicine, Udayana University, Sanglah General Hospital, Denpasar, Bali, Indonesia

Edited by: Ksenija Bogoeva-Kostovska ( Sumadi IWJ, Giri KGB, Pemayun CKD, Santosa C. High Expression of Parathyroid Hormone-related Protein an umor Necrosis Factor- $\alpha$ in Cancer Cells as Risk Factors for Hypercalcemia in Bone Metastases Lytic Lesions. https//doi.org/10 3889/oamims 2021.5951 Keywords: Bone metastases; Hypercalcemia; Parathyroid hormone-related protein; Tumor necrosis factor- $\alpha$ *Correspondence: Made Wahyu Dharmapradita, Department of Orthopaedics and Traumatology, Faculty of Medicine, Udayana University, Sanglah Genera Hospital, Denpasar, Bali. Tel: +6281236715567. E-mail: g2a003111@gmail.com Received: 06-Mar-2021 Revised: 13-Apr-2021 Copyright: $\odot 2021$ Made Wahyu Dharmapradita, madi, Kadek Gede Bakta Giri, Cokorda Krishna Dalem Pemayun, Claudia Santosa Funding: This research did not receive any financial Competing Interests: The authors have declared that no competing interests exist Open Access: This is an open-access article distributed under the terms of the Creative Commons AttributionNonCommercial 4.0 International License (CC BY-NC 4.0)

\section{Abstract}

BACKGROUND: Cancer mortality is more commonly due to metastases of the tumor to other organs and the complications that accompany it than the tumor growth itself. Until recently, metastasis has been an insurmountable problem.

AIM: As the most frequent site of metastases, apart from the lungs and liver, tumor metastases to bone are associated with hypercalcemia which is fatal for the affected patient.

METHODS: This study used a case-control study design. The case group consisted of paraffin block samples derived from bone metastatic cancer cell biopsies of patients with hypercalcemic lytic lesions. The control group consisted of paraffin block samples derived from bone metastatic cancer cell biopsies of patients with non-hypercalcemic lytic lesions. Radiological examination was performed to examine the presence of lytic lesions, followed by data collection of serum calcium levels. The data obtained from the histopathological examination was confirmed along with the availability of paraffin blocks of bone metastasis cancer cell biopsy samples, and immunohistochemical analysis was performed to determine the expression of tumor necrosis factor- $\alpha$ (TNF- $\alpha$ ) and parathyroid hormone-related protein (PTHrP). A Mann-Whitney test was performed to determine the expression of TNF- $\alpha$ and PTHrP between hypercalcemia and non-hypercalcemia groups. To identify the cut-off point, Youden index on receiver operating characteristic was used, then the optimal cut-off point was determined where the sensitivity and specificity curves intersect. Analysis of risk factor assessment was done by creating a $2 \times 2$ cross-tabulations and calculating the association size in the form of odds ratio (OR)

RESULTS: The expression of PTHrP and TNF- $\alpha$ in the case group was significantly different from the control group with $p<0.05$. The cut-off point for PTHrP expression was 267.5 with an area under the curve of 0.93 , indicating a high accuracy value. The cut-off point for TNF- $\alpha$ expression was 227.5 with an area under the curve of 0.68 , indicating a moderate accuracy value. The OR between hypercalcemia and non-hypercalcemia to PTHrP expression was 110.3 (Fisher's exact statistical test obtained $p<0.05$ ), while the OR between hypercalcemia and non-hypercalcemia to TNF- $\alpha$ expression was 7.27 (Fisher's exact test statistical obtained $p=0.01$ )

CONCLUSION: Significant differences in the expression of PTHrP and TNF- $\alpha$ were found between patients with bone metastases lytic lesions with hypercalcemia compared to those without hypercalcemia. We can conclude that either a high level of PTHrP expression and/or TNF- $\alpha$ expression in cancer cells can serve as risk factors for hypercalcemia in patients with bone metastatic lytic lesions

\section{Introduction}

Cancer mortality is more commonly due to metastasis of the tumor to other organs and the complications that accompany it than the growth of the tumor itself. Each year 350,000 people die from bone metastases in America. Bone is the site of the most frequent occurrence of metastases other than lung and liver. In prostate and breast cancer patients, bone metastases have a prevalence of more than $70 \%$ [1]. Tumor metastases to bone are associated with hypercalcemia which is fatal for the patient.
Cancer-related hypercalcemia has a poor prognosis, in which $80 \%$ of patients will die within 1 year and the median survival time is 3-4 months [2].

Hypercalcemia leads to arrhythmias, which will lead to cardiac arrest and eventually to death. Thirty percent of cancer patients will have hypercalcemia. It is estimated that $50 \%$ of cancer patients with hypercalcemia will die within 30 days. With oncology and supportive therapy, patients with symptomatic hypercalcemia still have a poor prognosis with low survival rate [3], [4], [5], [6].

Hypercalcemia in bone metastases is associated with the local effect of the tumor where 
bone resorption occurs. The humoral factor is secreted in the form of paracrine or endocrine or, very rarely, is the result of excessive activation of Vitamin $\mathrm{D}$ by tumor cells. However, not all cases of bone metastases with lytic lesions resulted in hypercalcemia. In the case of advanced bone metastases causing massive local osteolytic, it is documented that only $20 \%$ of patients with cancer patients are associated with hypercalcemia. The cause of this still cannot be explained until now [6], [7].

The cause of the release of calcium from the bone microenvironment is due to increased osteoclast activity. Parathyroid hormone-related protein (PTHrP) and cytokines such as tumor necrosis factor- $\alpha$ (TNF- $\alpha$ ) are mediators that are known to support bone resorption through osteoclast activity. PTHrP is a paraneoplastic protein that takes its name from its similarity between the amino-terminal portions and is related to the portion of the parathyroid hormone [8]. PTHrP acts on osteoblasts that secrete RANKL to activate osteoclasts [9]. PTHrP is secreted by tumor cells then binds to the PTHRP1 receptor on osteoblasts and perhaps even on osteocytes which further increases RANKL expression. PTHrP also decreases the production of Osteoprotegerin. RANKL then binds to RANK on the osteoclast precursor. This binding activates the transcription factor AP1 through JUN N-terminal kinase and NF- $\kappa B$ through $\kappa-B$ kinase inhibitor which in turn stimulates osteoclastogenesis and causes osteoclastic resorption of the bone matrix [5], [10], [11], [12].

TNF- $\alpha$ stimulates bone resorption by osteoclasts in vitro and causes hypercalcemia in vivo [6]. TNF- $\alpha$-mediated osteoclastogenesis consists of 2 different mechanisms, RANK dependent and RANK independent. During the early phase of osteoclastogenesis, TNF- $\alpha$ increases the proliferation and differentiation of osteoclast precursors in response to macrophage-colony stimulating factor and by stimulating c-Fms expression, this is referred to as the independent RANK pathway. The osteoclast precursor will differentiate into mature osteoclasts in the presence of RANKL; here, TNF- $\alpha$ acts on RANK, so it is called the RANK dependent pathway [13].

Recognizing risk factors is vital and if hypercalcemia is left untreated, it will quickly worsen and can be life-threatening. Recognizing the role of PTHrP and TNF- $\alpha$ as risk factors for hypercalcemia can aid in the investigation and facilitate appropriate management to prevent poor prognosis and extend the life expectancy of patients with bone metastases.

\section{Materials and Methods}

This research is an analytic observational study with a case-control study design. The case group consisted of paraffin block samples derived from bone metastatic cancer cell biopsies of patients with hypercalcemic lytic lesions. The control group consisted of paraffin block samples derived from bone metastatic cancer cell biopsies of patients with non-hypercalcemic lytic lesions. The research was conducted at Orthopaedic and Traumatology Polyclinic and the Department of Anatomical Pathology, Sanglah Hospital, from November to December 2020. The number of samples was determined using a two-way hypothesis test resulted in a total sample size of 46 patients per group. The samples were selected from the database of orthopedic patients at Sanglah Hospital from 2016 to 2019. Consecutive sampling technique was performed where samples that met the inclusion criteria were selected until the number of samples was met. Inclusion criteria include all bone metastatic cancers with lytic lesions on X-ray, good paraffin block preparations sufficient for examination, laboratory results showing hypercalcemia, and no hypercalcemia. The exclusion criteria are as follows: Patients with a history of or in treatment with drugs containing Thiazide, Bisphosphonate, or RANKL antibodies (Denosumab), a history of or in hyperparathyroidism conditions, patients with a history of or in conditions of intoxication of Vitamin $A$ and Vitamin D, damaged paraffin block reparations, and unavailable laboratory data on calcium levels.

\section{Research procedure}

First, data collection of cancer patients with bone metastases from orthopedic patient recapitulation data was carried out, then the patients were sorted according to the inclusion and exclusion criteria. Patients with lytic lesions, as proven by the X-ray, were collected and serum calcium data were obtained. Following that, the histopathological examination data were confirmed and the availability of paraffin blocks of the bone metastasis cancer cell biopsy samples at the Anatomical Pathology Lab of Sanglah Hospital was examined. Immunohistochemical analysis was then carried out to determine the expression of TNF- $\alpha$ and PTHrP.

\section{Calcium examination procedure}

Blood samples from the patients were obtained using a tube without EDTA and then centrifuged for 15 min. Serum supernatant was taken and treated with COBAS 6000 machine.

\section{PTHrP and TNF- $\alpha$ immunohistochemical examination procedure}

To get an image of PTHrP expression in the tissue, immunohistochemical staining was performed using the Avidin-Biotin Complex (ABC) method. Paraffin blocks were cut using Leica RM2235 microtome with a thickness of $3 \mu \mathrm{m}$, then dried and affixed to a poly-L-lysine 
coated slide. The slides were heated on a slide warmer at $60^{\circ}$ for 30 min. Furthermore, deparaffinization with xylol was performed gradually (xylol I, II, III) for $5 \mathrm{~min}$ each, followed by rehydration in decreasing concentrated alcohol (absolute alcohol, 96\%, and $80 \%$ ) gradually for $4 \mathrm{~min}$ each. Then, the endogenous peroxidase was neutralized with hydrogen peroxide/methanol $0.5 \% \mathrm{v} / \mathrm{v}$ for $10 \mathrm{~min}$. The slides were washed in running water, then heat-induced retrieval antigen was carried out using Tris EDTA buffer solution ( $\mathrm{pH} \mathrm{9.0)} \mathrm{for} 3 \mathrm{~min}$. The slides were washed with Phosphate-buffered Saline (PBS) pH 7.4 for $5 \mathrm{~min}$, then the slides were coated with normal serum for $10 \mathrm{~min}$. Slides were incubated with primary antibody (polyclonal antibody PTHrP, Elabscience with 1:100 dilution; TNF- $\alpha$ monoclonal antibody, and Elabscience with 1:100 dilution) for $1 \mathrm{~h}$. The slides were washed with PBS for $5 \mathrm{~min}$ and then incubated with biotinylated secondary antibodies for $15 \mathrm{~min}$. Slides were washed with PBS for 5 minutes then incubated with $A B C$-horseradish peroxidase (ABC-HRP) for 15 minutes. Slides were then washed with PBS for 5 min and incubated with diaminobenzidine tetrahydrochloride for $1 \mathrm{~min}$. The slides were rinsed under running water and counterstained with hematoxylin. Slides were rinsed under running water then immersed in saturated lithium carbonate for $1 \mathrm{~min}$. Dehydration and clearing processes were performed, then the slides were closed with a mounting solution and coverslip [14], [15].

The PTHrP and TNF-a review was conducted blindly by researchers who did not know the histopathological diagnosis of the cases they were evaluating. Slides were examined at $400 \times$ magnification, evaluation was performed on the cytoplasm of tumor cells colored brown when positive [16]. Breast cancer tissue was used for PTHrP positive and negative control. Tonsil tissue was used for TNF-a positive and negative control. The PTHrP and TNF-a expression score was carried out using the Histo-Score (H-Score) with a total range of $0-300$ which is the sum of the percentage of positive tumors (range 0-100) and the intensity score $(0=$ negative, $1=$ weak, 2 = intermediate, $3=$ strong $)$ [17] .

\section{Data analysis}

Descriptive analysis was used to determine the standard deviation, mean, and median, while frequency distribution was used to describe general characteristics and variations between groups. The normality of data was performed using Shapiro-Wilk test.

To determine if there is a difference in the TNF- $\alpha$ and PTHrP expression between the hypercalcemia and non-hypercalcemia groups, a Mann-Whitney test was performed. To identify the cutoff point for TNF- $\alpha$ and PTHrP expressions, a Youden Index on receiver operating characteristic (ROC) is used, the optimal cut-off point was determined where the sensitivity and specificity curves intersect. Youden's Index Formula = Sensitivity + Specificity -1 .
The index with the highest value was selected as the intersection point on the ROC curve [18], [19]. Risk Factor Assessment was carried out by creating a $2 \times 2$ cross-tabulations and calculating the association size in the form of odds ratio (OR). All data analysis was performed with a significance level of $\alpha=0.05$ or $95 \%$ confidence interval $(\mathrm{Cl})$ value.

\section{Results}

The study samples consisted of 23 paraffin blocks from the biopsy results of MBD patients with hypercalcemia and 23 paraffin blocks from those who were not hypercalcemic. Each group was stained with PTHrP antibody and TNF- $\alpha$ antibody.

\section{Normality test}

Table 1. Normality test for PTHrP expression, TNF- $\alpha$ expression, and calcium levels with ShapiroWilk test.

Table 1: Normality test for PTHrP expression, TNF- $\alpha$ expression, and calcium levels with Shapiro-Wilk test

\begin{tabular}{lllll}
\hline Variable & Group & $\mathrm{p}$ & $\mathrm{n}$ & Note \\
\hline PTHrP expression & Case & 0.00 & 23 & Not normal \\
& Control & 0.00 & 23 & Not normal \\
TNF- $\alpha$ expression & Case & 0.00 & 23 & Not normal \\
& Control & 0.46 & 23 & Normal \\
Calcium level & Case & 0.117 & 23 & Normal \\
& Control & 0.140 & 23 & Normal \\
\hline TNF: Tumor necrosis factor, PTHrP: Parathyroid hormone-related protein. & &
\end{tabular}

From the normality test, it was found that PTHrP expression in both the case and control group did not have a normal distribution, while TNF- $\alpha$ expression has variable normality distribution. The distribution of calcium levels has a normal distribution (Table 1).

\section{Characteristics of research subjects}

In general, the study sample consisted of 17 men $(37 \%)$ and 29 women $(63 \%)$. The mean age of the patients was $55.24( \pm 12.16)$ years. Age, sex, and tumor origin from solid organs did not differ statistically between case and control group (Table 2). Most types of tumors came from breast cancer (9 cases; $19.6 \%$ ) (Table 3). Most MBD locations were in the proximal femur region (12 cases; $26.1 \%$ ) and in the thoracic vertebrae region (16 cases; $34.8 \%$ ) (Table 4 ).

Table 2: Characteristics of research subjects

\begin{tabular}{llll}
\hline Characteristics & Case $(\mathrm{n}=23)$ & Control $(\mathrm{n}=23)$ & $\mathrm{p}$ \\
\hline Age (Mean \pm SD) year & $55.3( \pm 11.8)$ & $55.2( \pm 12 ., 8)$ & $0.326^{\mathrm{a}}$ \\
Sex & 10 & 7 & $1.000^{\mathrm{b}}$ \\
$\quad$ Male & 13 & 16 & \\
$\quad$ Female & $12.13( \pm 1.41)$ & $8.57( \pm 0.76)$ & $0.035^{\mathrm{a}}$ \\
Calcium level (Mean \pm SD) mg/dL & 280 & 240 & $0.000^{\circ}$ \\
PTHrP expression (median) & 250 & 225 & $0.042^{\mathrm{c}}$ \\
TNF- $\alpha$ expression (median) & 250 & \\
\hline${ }^{\mathrm{a}}$ t-test; ${ }^{\mathrm{b}}$ Chi-square; ${ }^{\mathrm{C}}$ Mann-Whitney. TNF: Tumor necrosis factor, PTHrP: Parathyroid hormone-related \\
protein.
\end{tabular}




\section{Differences in expression of PTHrP and $T N F-\alpha$ in the case and control groups}

Mann-Whitney test was performed to determine differences in the expression of PTHrP and TNF- $\alpha$. PTHrP expression in the group case was significantly different from the control group with a $p<$ $0.05(p=0.00)$ and the TNF- $\alpha$ expression in the case group was significantly different from the control group with a $p<0.05(p=0.04)$.

Table 3: Origin of bone metastatic cancer

\begin{tabular}{llllll}
\hline Origin of cancer & \multicolumn{2}{c}{ Group } & & Total & $\%$ \\
\cline { 2 - 3 } & Case & Control & & \\
\hline Adeno Ca & 5 & 3 & 8 & 17,4 \\
Squamous Cell Ca & 1 & 1 & 2 & 4,3 \\
Adeno Ca thyroid & 2 & 2 & 4 & 8,7 \\
Not otherwise specified & 5 & 3 & 8 & 17,4 \\
Ca Cervix & 2 & 0 & 2 & 4,3 \\
Clear cell carcinoma & 1 & 0 & 1 & 2,2 \\
Adeno Ca Gaster & 1 & 0 & 1 & 2,2 \\
Ca Nasofaring & 0 & 2 & 2 & 4,3 \\
Ca Mammae & 3 & 6 & 9 & 19,6 \\
Adeno Ca lungs & 3 & 4 & 7 & 15,2 \\
Adeno Ca Prostate & 1 & 1 & 2 & 4,3 \\
Total & 23 & 23 & 46 & 100 \\
\hline
\end{tabular}

\section{Hypercalcemia risk factors}

Bivariate analysis was performed on the independent variables PTHrP expression and TNF- $\alpha$ expression as risk factors for hypercalcemia in bone metastatic lytic lesions by calculating the OR. The calculation of the OR was done by cross-tabulating the case and control pairs. The cut-off point for the PTHrP expression variable was obtained using Youden Index at the intersection of the ROC curve. From the analysis, it was found that the cut-off point for PTHrP expression was 267.5. The results of PTHrP area under curve obtained a value of 0.93 ( $p=0.00 ; 95 \% \mathrm{Cl} ; 0.83-1)$ which means it has a high accuracy value [19]. Thus, an $\mathrm{H}$-Score below 267.5 belongs to the low PTHrP expression group and an $\mathrm{H}$-Score equal to or more than 267.5 belongs to the high PTHrP expression group.

Table 4: Location of bone metastatic cancer

\begin{tabular}{|c|c|c|c|c|}
\hline \multirow[t]{2}{*}{ Metastases location } & \multicolumn{2}{|c|}{ Group } & \multirow[t]{2}{*}{ Total } & \multirow[t]{2}{*}{$\%$} \\
\hline & Case & Control & & \\
\hline Proximal humerus & 1 & 0 & 1 & 2,2 \\
\hline Shaft humerus & 3 & 0 & 3 & 6,5 \\
\hline Distal humerus & 0 & 1 & 1 & 2,2 \\
\hline Scapula & 1 & 0 & 1 & 2,2 \\
\hline Proximal femur & 6 & 6 & 12 & 26,1 \\
\hline Shaft femur & 2 & 1 & 3 & 6,5 \\
\hline Distal femur & 1 & 0 & 1 & 2,2 \\
\hline Vertebra cervical & 0 & 1 & 1 & 2,2 \\
\hline Vertebra thoracal & 7 & 9 & 16 & 34,8 \\
\hline Vertebra lumbar & 2 & 2 & 4 & 8,7 \\
\hline Pelvic & 1 & 2 & 3 & 6,5 \\
\hline Total & 23 & 23 & 46 & 100 \\
\hline
\end{tabular}

The cut-off point for TNF- $\alpha$ expression variable was obtained using Youden Index at the intersection point coordinates of ROC curve. From the analysis, it was found that the cut-off point for TNF- $\alpha$ expression was 227.5. The results of TNF- $\alpha$ under curve area obtained a value of 0.68 ( $p=0.04 ; 95 \% \mathrm{Cl}$; 0.52-0.84) which means that it has a moderate accuracy value [19]. Thus, an $\mathrm{H}$-Score below 227.5 belongs to the low TNF- $\alpha$ expression group and an $\mathrm{H}$-Score equal to or more than 227.5 belongs to the high TNF- $\alpha$ expression group.
Table 5: Cross-tabulation of PTHrP expressions between case and control

\begin{tabular}{llll}
\hline Group & Case & Control & Total \\
\hline High PTHrP expression & 21 & 2 & 23 \\
Low PTHrP expression & 2 & 21 & 23 \\
Total & 23 & 23 & 46 \\
\hline OR=110.3 $(p=0.000, \mathrm{Cl} 95 \% ; 14.176-857.42)$. OR: Odds ratio, PTHrP: Parathyroid hormone-related \\
protein.
\end{tabular}

\section{Expression of PTHrP with hypercalcemia in bone metastases}

Using the PTHrP cut-off point 267.5, the OR between hypercalcemia and non-hypercalcemia to PTHrP expression was 110.3. Statistically, this OR was declared significant because with the Fisher's Exact statistical test, the $p<0.05(p=0.000)$ (Table 5), this means that higher PTHrP expression is a risk factor for hypercalcemia in bone metastatic lytic lesions. Immunohistochemical staining for PTHrP antibody can be seen in Figures 1 and 2.

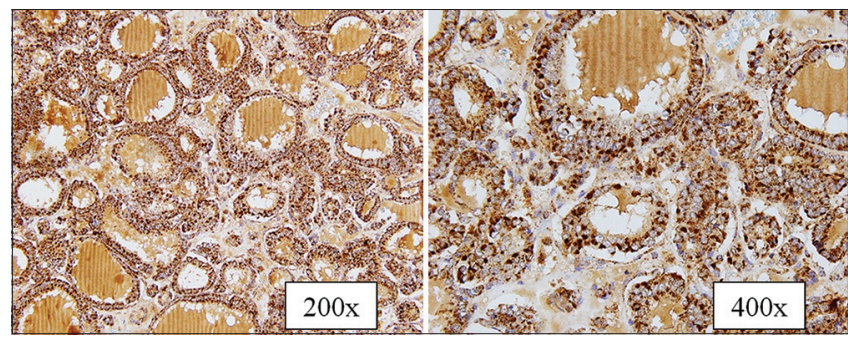

Figure 1: Immunohistochemical staining sample for parathyroid hormone-related protein (PTHrP) antibody in the case group. HistoScore 280, high PTHrP expression

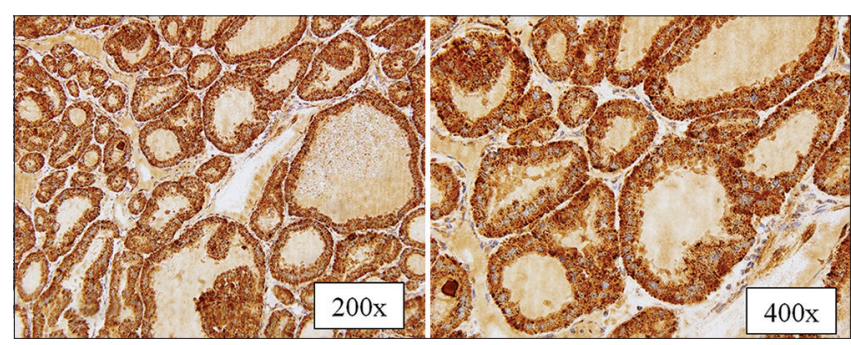

Figure 2: Immunohistochemical staining sample for parathyroid hormone-related protein (PTHrP) antibody in the control group. Histo-Score 250, low PTHrP expression

\section{TNF- $\alpha$ Expression with hypercalcemia in} bone metastases

Using TNF- $\alpha$ cut-off point of 227.5, OR obtained between hypercalcemia and non-hypercalcemia to TNF- $\alpha$ expression was 7.27

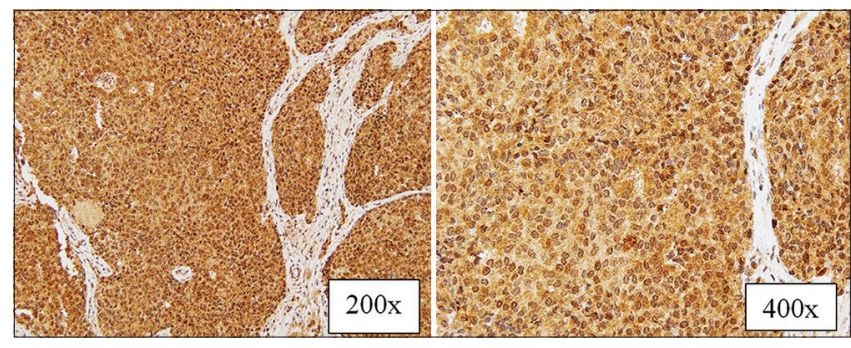

Figure 3: Immunohistochemical staining sample for tumor necrosis factor (TNF)- $\alpha$ antibody in the case group. Histo-Score 290, high TNF- $\alpha$ expression 
Statistically, the OR was significant because with the Fisher's Exact statistical test, the $p<0.05(p=0.01)$ (Table 6), this means that a higher TNF- $\alpha$ expression is a risk factor for hypercalcemia in bone metastases lytic lesions. Immunohistochemical staining sample for TNF- $\alpha$ antibody can be seen in Figures 3 and 4 .

Table 6: Cross-tabulation of TNF- $\alpha$ expressions between case and control

\begin{tabular}{|c|c|c|c|}
\hline Group & Case & Control & Total \\
\hline High PTHrP expression & 20 & 11 & 31 \\
\hline Low PTHrP expression & 3 & 12 & 15 \\
\hline Total & 23 & 23 & 46 \\
\hline
\end{tabular}

$\mathrm{OR}=7.27$ ( $\mathrm{p}=0.01, \mathrm{Cl} 95 \% ; 1.68-31.43)$. TNF: Tumor necrosis factor, OR: Odds ratio, PTHrP: Parathyroid hormone-related protein

\section{Discussion}

\section{Characteristics of gender, age, location of metastases, and cancer origin}

Research by Silva et al. (2019) reported that out of 1283 patients with lung cancer in its development, $11.9 \%$ of patients had bone metastases with an average age of 60 years old, with male $52.7 \%$. Based on age demographics, most bone metastases occur in adults over 50 years of age, while in contrast to most sarcomas which occur in adolescents or young adults (aged less than 30 years old). Therefore, bone-occupying mass in adults is more likely to be metastatic carcinoma than primary sarcomas of bone [20]. The gender in this study was different from other studies due to differences in the population where the study was conducted, different type of cancer, and the smaller number of samples.

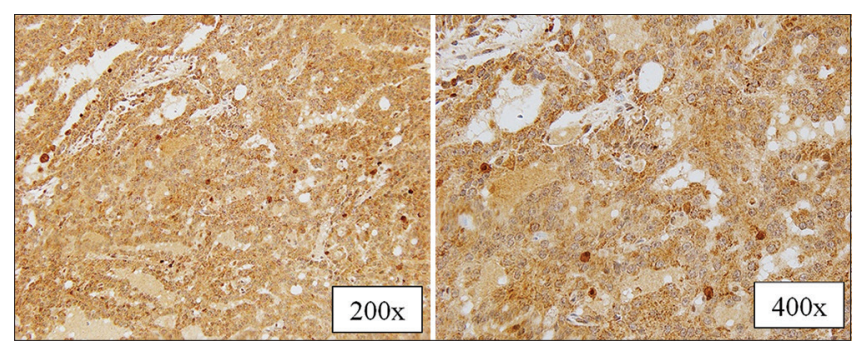

Figure 4: Immunohistochemical staining sample for tumor necrosis factor (TNF)- $\alpha$ antibody in the control group. Histo-Score 220, low TNF- $\alpha$ expression

Coleman et al. (2006) stated that primary cancer in the majority of bone metastases was breast cancer as much as $73 \%$ with vertebral region being the most metastases site by $20 \%$ followed by other places as much as 13\% [21]. The primary sites of cancer metastases in this study were the same as other studies, mostly from breast cancer. This is due to several factors: Breast cancer forms multiple cell adhesion molecules, including integrins, cadherins, osteopontin, bone sialoprotein, laminin, and type IV collagen which play a role in breast cancer cells, so they prefer to metastasize to bone. Breast cancer cells also produce PTHrP which activates stromal and osteoblast cells in the production of RANKL, eventually activating osteclasts so that bone resorption occurs and growth factors are released from the bone matrix [22].

The location of most metastases is in the vertebral region because the types of cancer originating from breast, thyroid, prostate, lung, kidney, and hematopoietic are more often metastasizes there. Thoracic vertebrae are the most frequently involved region in this study because it contains the largest volume of bone marrow to accept metastatic deposits [23]. Lung and breast cancers mostly metastasize to the thoracal region due to venous flow from the breast through the azygos connected to Batson plexus in the thoracal region, while lung cancer spreads through pulmonary veins and is distributed to the bone. Prostate cancer usually spreads to the lumbosacral region because prostate cancer flows through pelvic plexus in lumbar region [24].

\section{Expression of PTHrP in bone metastatic hypercalcemia}

PTHrP is a protein encoded by a single gene on the short arm of chromosome 12. At approximately 130 amino acid sequences, PTHrP has $10 \%$ the same structure as PTH. With a similar but not identical structure, PTHrP has similar activities like PTH such as agonist action on $\mathrm{PTH}$ receptors in the kidneys and bones, resulting in increased bone resorption and calcium reclamation in the kidneys. Specifically in bone, PTHrP causes bone resorption by increasing osteoclast activation and suppressing osteoblasts, without being followed by bone formation which causes an increase in the amount of calcium in the circulation [25], [26].

PTHrP has been shown to have a role in bone metastases. Iddon et al. (2000) in their study of bone metastases samples from patients with prostate cancer found 10 out of 14 samples expressed significant PTHrP ( $p=0.001)$ when compared with primary prostate cancer cells [27]. Previously Hayman et al. (1991) obtained similar results on immunohistochemical staining on 13 samples of bone metastases biopsy of patients with breast cancer, 12 of 13 samples of PTHrP positive expression (92.3\%) with $p<0.0001$ compared with those without bone metastases [27], [28].

Until now, there has been scarce publication on the expression of PTHrP in cases of bone metastases with hypercalcemia in humans. Miki et al. (2004) in their in vivo study on male S EB-17/lcr-scid mice aged 6-8 weeks that were injected with human lung cancer cells then given anti-PTHrP antibody intravenously, found an improvement in calcium levels and a lower amount of metastases compared to control group that was not given anti-PTHrP antibody [29].

One of the causes of hypercalcemia in cancer is bone metastases causing lytic lesions from osteoclast activity and calcium release. This process usually occurs 
in patients with multiple myeloma and metastatic solid organ tumors such as breast cancer. Breast cancer cells, for example, produce PTHrP locally and increase RANKL activity which in turn activates osteoclasts and causes lytic processes and calcium release [30], [31].

From this explanation, it is evident that PTHrP has an important role in hypercalcemia occurring in bone metastases. The results of this study indicate that $\mathrm{PTHrP}$ has a role in the incidence of hypercalcemia in bone metastatic patients, where cancer with bone metastatic and high PTHrP expression will increase the risk of hypercalcemia, causing higher morbidity and even mortality to patients.

\section{TNF- $\alpha$ expression in bone metastatic hypercalcemia}

Several studies have shown that TNF- $\alpha$ plays a role in the inflammatory process associated with carcinogenesis. TNF- $\alpha$ is produced by many types of cells, such as macrophages, neutrophils, fibroblasts, T cells, B cells, and tumor cells themselves. TNF- $\alpha$ has an important role in tumor progression and microenvironment, where this cytokine enhances angiogenesis and increases the invasion and migration of cancer cells, including metastases [32]. Hamaguchi et al. (2011) found in an in vivo study that administering infliximab, a TNF- $\alpha$ antibody caused a decrease of lytic lesions in mice with bone metastatic breast cancer cells [33].

Yu, et al. (2019) in a study of patients with nasopharyngeal cancer proved that the mean TNF- $\alpha$ expression was higher in cancer cells of patients with bone metastases compared to those without, although it was not statistically significant due to the small number of case samples. Correspondingly, serum TNF- $\alpha$ levels were proven to have a positive correlation with high invasion of cancer cells to bone and poor patient prognosis [34].

Mazaki et al. (2019) performed a real-time PCR test to samples taken from mice vertebrae with breast cancer metastases, proving an increase in TNF- $\alpha$ gene expression compared to IL-6, and this was in line with the results of immunohistochemical expression. It is evident that TNF- $\alpha$ affects lytic lesions in bone metastases [35]. Takahashi et al. (2003) studied 29 cancer patients with hypercalcemia and found that TNF- $\alpha$ levels in serum increased, though not significantly [36].

From the explanation of several studies above, it can be concluded that the role of TNF- $\alpha$ has not been proven statistically, although the results did show an increase in TNF- $\alpha$ level. This is different from the results of this study, which proved that TNF- $\alpha$ expression was significantly different between case and control group, with a sample size of 23 patients each. This difference may be due to differences in the number of cases and the design of the study. It can be concluded that TNF- $\alpha$ has a role in hypercalcemia in bone metastatic lytic lesions.

\section{Weaknesses of research}

This study was conducted on 46 cases of bone metastatic cancer, it is necessary to consider increasing the number of cases so that variations in cancer types can be reproduced. The only cytokine tested was TNF- $\alpha$ due to limited resources in this study. In the future, other cytokines supporting hypercalcemia process in bone metastases should be further investigated.

\section{Conclusion}

There were significant differences in the expression of PTHrP and TNF- $\alpha$ between patients with bone metastases lytic lesions with hypercalcemia compared to those without hypercalcemia. Higher $\mathrm{PTHrP}$ and TNF- $\alpha$ expression in cancer cells is a risk factor for hypercalcemia in patients with bone metastatic lytic lesions.

\section{References}

1. Huang JF, Shen J, Li X, Rengan R, Silvestris N, Wang M, et al Incidence of patients with bone metastases at diagnosis of solid tumors in adults: A large population-based study. Ann Trans Med. 2020;8(7):482. https://doi.org/10.21037/atm.2020.03.55 PMid:32395526

2. Seccareccia D. Palliative care files cancer-related. Can Fam Physician. 2010;56(3):244-6.

PMid:20228307

3. Bollerslev J, Pretorius M, Heck A. Parathyroid hormone independent hypercalcemia in adults. Best Pract Res Clin Endocrinol Metab. 2018;32(5):621-38. https://doi.org/10.1016/j. beem.2018.06.005

PMid:30449545

4. Wijaya I, Oehadian A, Sumantri R. Hypercalcemia of malignancy: Clinical characteristics and treatment outcome. Maj Kedokt Bandung. 2014;46(2):111-7. https://doi.org/10.15395/ mkb.v46n2.283

5. Wright LE, Guise TA. The role of PTHrP in skeletal metastases and hypercalcemia of malignancy. Clin Rev Bone Miner Metab. 2014;12(3):119-29. https://doi.org/10.1007/s12018-014-9160-y

6. Clines GA, Guise TA. Hypercalcaemia of malignancy and basic research on mechanisms responsible for osteolytic and osteoblastic metastasis to bone. Endocr Relat Cancer. 2005;12(3):549-83. https://doi.org/10.1677/erc.1.00543

PMid:16172192

7. Rosner MH, Dalkin AC. Onco-nephrology: The pathophysiology and treatment of malignancy-associated hypercalcemia. Clin $\mathrm{J}$ Am Soc Nephrol. 2012;7(10):1722-9. https://doi.org/10.2215/ cjn.02470312 PMid:22879438

8. Montgrain PR, Quintana R, Rascon Y, Burton DW, Deftos LJ, Casillas A, et al. Parathyroid hormone-related protein varies with sex and androgen status in nonsmall cell lung cancer. Cancer. 2007;110(6):1313-20. https://doi.org/10.1002/cncr.22922 


\section{PMid:17676588}

9. Clines GA. Mechanisms and treatment of hypercalcemia of malignancy. Curr Opin Endocrinol Diabetes Obes. 2011;18(6):339-46.

PMid:21897221

10. Pioszak AA, Parker NR, Gardella TJ, Xu HE. Structural basis for parathyroid hormone-related protein binding to the parathyroid hormone receptor and design of conformation-selective peptides. J Biol Chem. 2009;284(41):28382-91. https://doi. org/10.1074/jbc.m109.022905

PMid:19674967

11. Thomas RJ, Guise TA, Yin JJ, Elliott J, Horwood NJ, Martin TJ, et al. Breast cancer cells interact with osteoblasts to support osteoclast formation. Endocrinology. 1999;140(10):4451-8. https://doi.org/10.1210/endo.140.10.7037 PMid:10499498

12. Mundy GR. Metastasis to bone: Causes, consequences and therapeutic opportunities. Nat Rev Cancer. 2002;2(8):584-93. https://doi.org/10.1038/nrc867

PMid:12154351

13. Boyce BF, Li P, Yao Z, Zhang Q, Badell IR, Schwarz EM, et al. TNF-alpha and pathologic bone resorption. Keio J Med. 2005;54(3):127-31.

PMid:16237274

14. Susanto E. Peran Imunohistokimia p53 Dalam Membedakan Astrositoma Difus Dengan ASstrositosis: Studi Diagnostik; 2014.

15. Jammal MP, Da Silva AA, Filho AM, Côbo ED, Adad SJ, Murta EF, et al. Immunohistochemical staining of tumor necrosis factor- $\alpha$ and interleukin-10 in benign and malignant ovarian neoplasms. Oncol Lett. 2015;9(2):979-83. https://doi. org/10.3892/ol.2014.2781

PMid:25624918

16. Sufrida N, Hernowo BS, Nur IM, Suryanti S. Parathyroid Hormone-Related Protein (PTHrP) dan Osteonectin (OSN) Sebagai Petunjuk Adanya Penentu Metastasis ke Tulang pada Karsinoma Payudara Duktal Invasif. Vol. 20; 2011.

17. Wu CE, Wang CW, Huang WK, Yang CT, Wu YC, Hou MM, et al. Cytoplasmic and nuclear parathyroid hormonerelated proteins are opposing prognostic factors in patients with non-small-cell lung cancer who have undergone curative resection. Jpn J Clin Oncol. 2015;45(3):267-73. https://doi.org/10.1093/jjco/hyu202 PMid:25480982

18. Dahlan MS. Statistik Untuk Kedokteran Dan Kesehatan. $6^{\text {th }}$ ed Jakarta: Epidemiologi Indonesia; 2006.

19. Dahlan MS. Penelitian Diagnostik, Validitas and Reliabilitas. $2^{\text {nd }}$ ed. Jakarta: Epidemiologi Indonesia; 2018.

20. Chansky, H. A. and Gellman, H. Metastatic Bone Disease. 2020 Available from http://www.emedicine.medscape.com [Last accessed on 2020 Jan 05].

21. Zacharia B, Subramaniam D, Joy J. Skeletal metastasis an epidemiological study. Indian J Surg Oncol. 2018;9(1):46-51. https://doi.org/10.1007/s13193-017-0706-6

PMid:29563734

22. Theriault RL, Theriault RL. Biology of bone metastases. Cancer Control. 2012;19(2):92-101. https://doi. org/10.1177/107327481201900203 PMid:22487971

23. Rose PS, Buchowski JM. Metastatic disease in the thoracic and lumbar spine: Evaluation and management. J Am Acad Orthop Surg. 2011;19(1):37-48

PMid:21205766

24. Maccauro G, Spinelli MS, Mauro S, Perisano C, Graci C, Rosa
MA. Physiopathology of Spine Metastasis. Int J Surg Oncol. 2011;2011:107969. https://doi.org/10.1155/2011/107969 PMid:22312491

25. Sternlicht H, Glezerman IG. Hypercalcemia of malignancy and new treatment options. Ther Clin Risk Manag. 2015;11:1779-88. https://doi.org/10.2147/tcrm.s83681 PMid:26675713

26. Naafs MA. Parathyroid hormone related peptide (PTHrP): A mini-review. Endocrinol Int J. 2017;5(6):321-8.

27. Iddon J, Bundred NJ, Hoyland J, Downey SE, Baird P, Salter D, et al. Expression of parathyroid hormone-related protein and its receptor in bone metastases from prostate cancer. J Pathol. 2000;191(2):170-4. https://doi.org/10.1002/ (sici)1096-9896(200006)191:2<170::aid-path620>3.0.co;2PMid: 10861577

28. Hayman JA, Danks JA, Martin TJ. Localization of parathyroid hormone-related protein in breast cancer metastases: Increased incidence in bone compared with other sites. Cancer Res. 1991;51(11):3059-61.

PMid:2032246

29. Miki T, Yano S, Hanibuchi M, Kanematsu T, Muguruma H, Sone S Parathyroid hormone-related protein (PTHRP) is responsible for production of bone metastasis, but not visceral metastasis, by human small cell lung cancer SBC-5 cells in natural killer celldepleted scid mice. Int J Cancer. 2004;108(4):511-5. https://doi. org/10.1002/ijc. 11586

PMid:14696114

30. McDermott MT. Hypercalcemia of malignancy. In: Endocr Secrets. $6^{\text {th }}$ ed. Amsterdam, Netherlands: Elsevier; 2013. p. 142-4.

31. Vakiti A, Mewawalla P. Malignancy Related Hypercalcemia. In: Pathophysiology. Treasure Island, FL: StatPearls Publishing; 2019. p. 1-4.

PMid: 11074064

32. Sethi G, Sung B, Aggarwal B. TNF: A master switch for inflammation to cancer Gautam Sethi, Bokyung Sung, Bharat B. Aggarwal. Front Biosci. 2008;13:5094-107. https://doi. org/10.2741/3066

PMid:18508572

33. Hamaguchi $T$, Wakabayashi $H$, Matsumine A, Sudo A, Uchida A. TNF inhibitor suppresses bone metastasis in a breast cancer cell line. Biochem Biophys Res Commun. 2011;407(3):525-30. https://doi.org/10.1016/j.bbrc.2011.03.051

PMid:21414299

34. Yu Y, Ke L, Xia WX, Xiang Y, Lv X, Bu J. Elevated levels of TNF- $\alpha$ and decreased levels of CD68-positive macrophages in primary tumor tissues are unfavorable for the survival of patients with nasopharyngeal carcinoma. Technol Cancer Res Treat. 2019;18:1-11. https://doi.org/10.1177/1533033819874807 PMid:31522611

35. Mazaki A, Orita $\mathrm{S}$, Inage $\mathrm{K}$, Suzuki M, Abe $\mathrm{K}$, Shiga $\mathrm{Y}$, et al Tumor necrosis factor- $\alpha$ produced by osteoclasts might induce intractable pain in a rat spinal metastasis model of breast cancer. Spine Surg Relat Res. 2019;3(3):261-6. https://doi. org/10.22603/ssrr.2018-0106

PMid:31440686

36. Takahashi S, Hakuta M, Aiba K, Ito Y, Horikoshi N, Miura M, et al. Elevation of circulating plasma cytokines in cancer patients with high plasma parathyroid hormone-related protein levels. Endocr Relat Cancer. 2003;10(3):403-7. https://doi. org/10.1677/erc. 0.0100403

PMid: 14503917 